Cinémas

Revue d'études cinématographiques

Journal of Film Studies

\title{
Theoretical Apparitions of Haiku : An Intermedial Interrogation of Modernity
}

\section{Tollof Nelson}

Volume 10, numéro 2-3, printemps 2000

Cinéma et intermédialité

URI : https://id.erudit.org/iderudit/024822ar

DOI : https://doi.org/10.7202/024822ar

Aller au sommaire du numéro

Éditeur(s)

Cinémas

ISSN

1181-6945 (imprimé)

1705-6500 (numérique)

Découvrir la revue

Citer cet article

Nelson, T. (2000). Theoretical Apparitions of Haiku : An Intermedial Interrogation of Modernity. Cinémas, 10(2-3), 185-203.

https://doi.org/10.7202/024822ar

\section{Résumé de l'article}

$\mathrm{Au}$ tournant du XXe siècle, la traduction et la réception de la poésie du haïku en Occident a permis de faire des apparitions théoriques au-delà du dispositif littéraire. Le haïku s'est réinventé comme une pratique de poésie devenue une technique audiovisuelle : le haïku comme ligne de fuite, médium d'une autre relation à la langue et à l'image. Modèle hybride des arts modernistes (poésie, photographie, cinéma), le haïku a véhiculé de multiples théories pour articuler l'expérience d'une nouvelle économie spatio-temporelle des images. Mode d'écriture par fragments laconiques, gestes du quotidien et ombres de mémoire, le haïku a mobilisé une relation de mouvement, d'opacité et de distance à la langue. 


\title{
Theoretical Apparitions of Haiku: An Intermedial Interrogation of Modernity
}

\section{Tollof Nelson}

\begin{abstract}
RÉSUMÉ
Au tournant du $X X^{e}$ siècle, la traduction et la réception de la poésie du haiku en Occident a permis de faire des apparirions théoriques au-delà du dispositif littéraire. Le haïku s'est réinventé comme une pratique de poésie devenue une technique audiovisuelle: le haïku comme ligne de fuite, médium d'une autre relation à la langue et à l'image. Modèle hybride des arts modernistes (poésie, photographie, cinéma), le haïku a véhiculé de multiples théories pour articuler l'expérience d'une nouvelle économie spatio-temporelle des images. Mode d'écriture par fragments laconiques, gestes du quotidien et ombres de mémoire, le haïku a mobilisé une relation de mouvement, d'opacité et de distance à la langue.
\end{abstract}

\section{ABSTRACT}

At the turn of the twentieth century, the translation and the reception of haiku poetry allowed for theoretical advances beyond the purview of the literary. The haiku-idiom reinvented itself as a practice of poetry as audio-visual technique: haiku as a line of flight, medium of another relationship to language and to images. A hybrid-model of the modernist arts (poetry, photography, film), the haiku-idiom became a vehicle for theories articulating the experience of a new spatio-temporal economy of images. As a mode of writing in laconic fragments, gestures of everyday-life, and shadows of memory, the haiku-idiom mobilized 
for others a relationship of movement, opacity, and distance to language.

For artisans of the image, the haiku-idiom has mediated the conception of being in the world at a crucial historical epoch, from the turn of the twentieth century onwards, when the language market was being challenged by the increasing hegemony of the image ${ }^{1}$. Coinciding with specific technological transformations of mass movements of media such as the broader, more rapid circulation of newsprint, radio waves, photography and industrial cinema, this epoch has witnessed the emergence of a practice of haiku-poetry beyond versewriting that may be qualified as intermedial. This intermedial practice of haiku-poetry holds an interesting place in the history of recent media trends, as it ushered in a radical transformation of thinking from aesthetic to epistemological categories, from a work-oriented to a medium-oriented conception of art and reality, or technics and mediation. The following four-part series of reflections situates some of the suggestive theoretical advances concerning the haiku within this transformation. However, a word of methodological caution is necessary before proceeding; the topics, which comment upon the work of poets as distinctive and incomparable as Ezra Pound or Andrei Tarkovsky for example, are interrelated for extra-historical reasons as exemplary sites for the "problematization" of representation. This essay does not attempt a comparative history of the arts and literature, nor does it propose to outline or synthesize the principles of a universal haiku-poetics; instead, it explores how the haiku-idiom has put the subject-centered epistemology of modernity into question by opening up new relations between the subject and the world through the medium of language, photography and cinematography.

\section{Imagist-Vorticist Ideogram}

IN A STATION OF THE METRO

The apparition of these faces in the crowd; Petals on a wet, black bough. (Pound, 1957 [1913], p. 35). 
Orientalism married Modernism through the haiku aesthetic of arts as theorized and promulgated by Ezra Pound's Imagist and Vorticist rnanifestos before WWI (1908-1914). The fruitful vitality of such an exotic marriage proclaimed the idea of an American renaissance and projected a prophetic artist state of West meets East by forging the principles that might meet the future capacities of a dynamic "imaging" of ideas, a kinetic poetry diagramming the dynamic forms of Nature, an ideogrammic Image ${ }^{2}$. Pound explained the principle of the Image as a kind of speech in itself, beyond the ornamental or formulated use of speech, a direct treatment of things. The image, however, is not simply concrete but phenomenological; it is " $[. .$.$] that$ which presents an intellectual and emotional complex in an instant of time" (Pound, 1970 [1913], p. 4). Nor is the oneimage poem simply visual, as it generates a kind of paratactic superposition. Such a superposition is heard "In a Station of the Metro" as the semantic double of the word "apparition," meaning flashing appearance and ghostly flash, and is seen by the pallid/pure double of commuter faces and fallen petals. This superposition is also felt as the juxtaposition of the acceleration and the solitude of modern urban experience to the mythical repose of the Oriental garden. It captures and combines "[...] the essentiality of the conceptual image with the definiteness of the perceptual image[...]" (Schneidau, 1969, p. 45).

Pound's experiments with haiku poetry catalyzed new energies in popular culture and left its mark on the history of American literature in the generation of H.D., Amy Lowell, William Carlos Williams, Carl Sandburg, Marianne Moore, and Wallace Stevens. Alongside more popular translations and literary histories of haiku, Pound's work continued to exert an influence on the 60's beat-generation of poets like Allen Ginsberg, Gary Synder, and Jack Kerouac. It is as if the haiku idiom gave rights to these writers that their own literature refused them the right, as Roland Barthes notes, to a "breach of meaning" through which one might attain notability "at little expense", the entitlement to strike the "rhetorical labor" of moral exposition by writing trivial and ordinary impressions in a "thin horizon of words ," and the lure of the chiseled and 
simple perfection of "the classical" coupled with the profound spontaneity of "the romantic" (Barthes, 1985 [1970], p. 69).

Early on in his career, Pound renounced the "Imagist" movement, hatched overnight in London in 1912, for its tendency to propagate a milksop, static impressionism in affiliated writers. Pound constantly redefined the imagist aesthetic in vital terms and figures: "The image is not an idea. It is a radiant node or cluster; it is what I can, and must perforce, call a VORTEX, from which, and through which, and into which, ideas are rushing" (Pound, 1970, p. 92). This grammar of ideas projected an entire battery of artistic desires, plastic powers, and spatio-temporal transformations to contend with the dominant aesthetics of Romantic symbolism and Victorian narrative and to orient the machine-aesthetic of Futurism with the energies of political technocracy and industrial capital. It should be remembered that the ideogrammic principles of superposition, collision, and movement were formulated as a generalized or correlated modernist aesthetic applicable beyond literature to painting, sculpture, and music. Simply put, the efficacy of haiku poetics, as it crystallized what Pound called "the primary pigment," regenerated and founded these arts in the twentieth century.

Curiously enough, this historical change pushed Ezra Pound to seek new powers for images in the exotic language market of Sinology; his modernist poetics were re-invented in the geopolitical image of the Oriental-other. For example, during WWI and coterminous with his vorticist activity, Pound carried on translating ancient Chinese poetry Cathay (1915) in addition to his work editing the unpublished manuscripts of the late Sinologist and Art-historian, Ernest Fenellosa, such as The Chinese Written Character as a Medium for Poetry (1918). Jacques Derrida emphasizes the "historic significance" of the Pound-Fenellosa connection as a decentering of the transcendental authority eclipsing writing to speech, unattainable by science or philosophy since Nietzsche but made secure by "an irreducibly graphic poetics" and overturning the dominant logico-grammatical category of "being" in the Western episteme of language (Derrida, 1976 [1967], p. 92). As 
Derrida notes, Fenellosa considered the intolerant resistance exerted by the poetry of Chinese script to being translated by Aristotelian categories of language and parts of speech. In Fenellosa's vision, these categories are melted down "in the inner heat of thought" through the act of translation, that is, in the recognition of the graphical and purely verbal nature of Chinese script which, in imitation of Nature's forces, is moved to resound with a "transitive power of agency" in which subject and predicate, noun and object, are "only terminal points of a continuous action" (Fenellosa, 1991 [1918], p 11-17).

Epistemological considerations aside, it should be recalled that haiku ideo-grammatology constituted a kind of cultural superposition of East and West like Pound's "In a Station of the Metro," through a temporal montage of the mythical and the modern. It found its inspiration, courage, and mouthpiece through the imagination of the Oriental-other: an East of reclusive and ancient Haiku masters and Noh plays, an East closer to the springs and forces of Nature, the verbal saps and metaphorical transports of dynamic language, an East of unpolluted civilization and inexhaustible wisdom and an East of virgin, silken sexuality. On the discursive level of the imagination of cultures, this serialization of aesthetic programs projected an intercultural act of ventriloquism in which the "West" painted its own mask in oriental forms and heard its own voice by throwing it through the lips of the mute marionette.

This "muteness" of Japanese life continued on even into the sophisticated chapters of Roland Barthes' L'Empire des signes (1970), which for all of its insights, may be read in the light of Lisa Lowe's critique of "The Desires of Postcolonial Orientalism[...]" ultimately as a traveller's "poetics of escape," a utopian search for an "Oriental cultural text", like the four chapters dedicated to haiku poetry, that would "transcend the semiology and the ideology of the signifier and the signified, to invent a place that exceeds binary structure itself" (1991, p. 154). This haiku act of ventriloquism, far from constituting grounds for a moral indictment, might be stated in a positive way as well. Instead of apprehending a system of the traits of

Theoretical Apparitions of Haiku : An Intermedial Interrogation of Modernity 
Japanese culture and life through picturesque clichés, Barthes' essay raises questions about the problems of cultural representation generally. Among them, this epistemological dilemma: what is the status of the critical reflex, the effort to move beyond the discourse of representation, since it is always already conditioned to move within the imaginary of language and cultural text? In either instance, between Pound and Barthes, the reception, translation, and theorization of haiku poetry mobilized an economy of language that, while making representation problematic and earnestly seeking the possibility of a semiology of difference and mutation, reaffirmed a powerful, age-old imaginary of the Oriental-other. And yet... haiku-action always opens the possible future of this "and yet...".

\section{Haiku-Technics}

Créer n'est pas déformer ou inventer des personnes et des choses. C'est nouer entre des personnes et des choses qui existent, et telles qu'elles existent, des rapports nouveaux (Bresson, 1975, p. 27).

Robert Bresson's Notes sur le cinématographe reads like a wellthumbed, pocket-sized book of haiku with its short notes of aphoristic wisdom and austere simplicity that speak less of aesthetic principles than of a way of being between the world and audio-visual technique. This duality, of aesthetic principle versus a way of being-between, suggested by different ways of practicing haiku poetry as audio-visual technique, may be more richly explored through the comparision of two well-known Russian film-directors and theoreticians, Sergueï Eisenstein and Andrey Tarkovsky. Eisenstein, in the article "The Cinematographic Principle and the Ideogram," proposes a dialectical understanding of film form in the theory of montage, a theory that might prepare the way for an intellectual cinematography. Montage theory is developed by constant analogy to the haiku, "[...] the most laconic form of poetry [...] hieroglyphs transposed into phrases [...] montage phrases. Shot lists" (1957, p. 92). Almost echoing Pound's "Imagist" aesthetic he 
remarks: "The simple combination of two or three details of a material kind yields a perfectly finished representation of another kind -- psychological" (p. 93). This psycho-genesis of meaning and abstraction is achieved by means of a chain of signaletic material, a mise-en-scène of image-conflicts : conflicts between a series of graphic distortions, scales, volumes, masses, depths, lights, and durations. Shots are conceived as montage cells in the total make-up of film form; they are always subordinated to a tertiary organization of movement, action, and narration.

Yet Eisenstein, in the will to systematize a dialectic of strips and cuttings, to found all film phenomena according to the blocking and the building of montage, and to produce psychological abstractions out of the empirical clips and collisions of images, is radically at odds with the less willful spirit of haiku poetry, despite adhering to the ideogrammic principle. This perhaps forms the central irony of Eisentstein's Film Form, that the immense, architectural edifice of film montage would be imagined in the fugitive atmosphere of the haiku idiom. The haiku idiom as the poetic practice of audiovisual technique, would not merely question the ideogrammic aesthetic but would put into question the institutional framework of its principles as grounded in the epistemology of modernity. In this instance, Eisenstein's ideogrammic principle of montage reveals what Heidegger has called the culminating trait of Western metaphysics, the discursive organization of the instrumental representation of technology ${ }^{3}$ : the means of framing, empowering and engendering complete control over the reproduction, ordering and emplacement of the objectworld-as-picture for a governing subject (artist, party, State).

Andrey Tarkovsky's Sculpting in Time (1986) offers one of the most illuminating critiques of Eisenstein's theory of the haiku idiom and may be considered in the light of Heidegger's questioning. Although Tarkovsky constantly re-inscribes his critique of Eisenstein's montage as a foil to his own search for the aesthetic specificity of cinematography, his experience may be characterized as a "questing after technics" "which opens metaphysical insights beyond the purview of a poetics of film. 
For example, Tarkovsky displaces the idea of montage as the essential organizing element in film by discussing how montage is already presupposed, given by things as they present themselves in time and in the rhythm and intensity of their duration through film. Rather than producing a third sense, invisible and abstract, from the collision of images, montage can organize a unique threshold of perception in which and through which time is sculpted in terms of the rhythmic expression of the being of things ${ }^{5}$. The temporal fabric of the world is prior to montage and materially transforms the place of the subject. The "director" is not an architect-genius who, on the editing table, re-creates the world in his image through the clips and collisions of images; rather he is one who, in "directing" the pipelines of time pressures that inhere in shots like streams of water, becomes fluid and continuous with the temporal materiality of a world which is cooperatively creative and dynamic (p. 113-115).

This reversal of the instrumental representation of technology may, in Heidegger's words, be characterized by the interanimating relationship between the concepts of technics, poesis, and phusis, concepts the uncanny familiarity and strangeness of which tease thought into a different kind of wondering and questioning, in the oppositions of the modern to the ancient Greek world. For example, causality is not thought of as an effecting of results - for this would be equal to reducing the world to reporting itself as standing-reserve; instead, causality is thought of as a bringing-forth of material relationships of coresponsibility (Heidegger, 1977, p. 6-8). A silversmith does not simply stamp out the shape of the chalice in some resistant material, but, in his making of a work, harbours-forth the material, formal, final, and efficient modes of occasioning; this preserves and opens, in the dynamic materiality of its substance, a net-work of relations to space, time, self, and world. Technics is not thought of as a setting-upon or a challenging, but as a matter of being entirely at home in a craft of the fine arts or of the arts of the mind; related to the notion of episteme, technics is explored as "a mode of revealing," less technical than scientific expertise and less formal than artistic mastery. Technics belongs to bringing-forth, the arising-of-something-out- 
of-itself in poesis and phusis. In this, technics has the character of dynamic becoming and reveals its affinities to the way a flower bursts into bloorn (phusis) or in the way a silversmith brings about the making of the chalice (poesis).

Without referring to these concepts, Tarkovsky does articulate something of this alternative in the consistent comparison he makes between the experience of reading haiku poetry and the practice of audio-visual technique, or what may be called "haiku-technics." This analogy does not merely embellish his central remarks, concerning the mediation of rhythmic pressures of time, but prepares the ground for them to come to light:

\begin{abstract}
What captivates me here is the refusal even to hint at the kind of final image meaning that can be gradually deciphered like a charade. Haiku cultivates its images is such a way that they mean nothing beyond themselves, and at the same time they express so many things at once that it is not possible to catch their final meaning. The more closely the image corresponds to its function, the more impossible it is to constrict it within a clear intellectual formula. The reader of haiku has to be absorbed into it as into nature, to plunge in, lose himself in its depth, as in the cosmos where there is no bottom and no top (p. 106).
\end{abstract}

The double condition of the cinematographic image, as irreducible to a definite meaning and as undecipherable polysemy, overturns Eisenstein's notion of the haiku as a laconic shot-list, to be subsumed under the generation of psychological montage-effects. As Barthes remarks,

Deciphering, normalizing, or tautological, the ways of interpretation, intended in the West to pierce meaning, i.e., to get into it by breaking and entering [...] cannot help but failing the haiku; for the work of reading which is attached to it is to suspend language, not to provoke it $[\ldots]$ (p. 72).

Audio-visual technique repeats the experience of reading something as intelligible and yet as inscrutable as haiku poetry. This 
is not as a formal consideration of how it invests a wealth of meaning in terse form, but because it has the "negative capability" to suspend the meaning of anything at all, avoiding interpretation and symbolic representation entirely. For Barthes the "exemption of meaning" in haiku poetry marks the possibility of attaining in language the measure of the Zen satori, an empty, spherical and pure echo of nothingness. Yet for Tarkovsky this exemption permits the plunging dive through a salient language of pure events beyond the barrier dividing thought and cosmos, intellectual life and nature. In the midst of Tarkovsky's remarks on haiku poetry, he discusses the poetic image as created through a special form of observation, "made incarnate, visible, and four dimensional"; it embodies "a glimpse of the truth permitted to us in our blindness," an "indivisible and elusive" correlation and contact between human consciousness and the palpable world ${ }^{6}$.

It is clear that Tarkovsky is searching for a non-instrumental relationship to cinematography through the practice of haiku poetry, a relationship configured between technics, medium, and language. This questing comes to light in his practice of audiovisual technique. The post-utopian aftermath of all of his films, from Ivan's Childhood (1962) to The Sacrifice (1986), should be understood from this perspective. Why? Because Tarkovsky's films and theories articulate the experience, through the rhythmic pressures of imminent apocalypse, of a metaphysical quest through the ruins of technology as contrivance and are not motivated by a nostalgic regress to counter the progress of technocracy, nor by a humanist lamentation against the vices of war. It is never simply a question of getting technology "spiritually in hand". As Heidegger notes, even this response is conditioned by the instrumental representation of technology: "The will to mastery becomes all the more urgent the more technology threatens to slip from human control" (p. 5). Instead, it is by questing after technics, belonging to the bringing-forth of poesis and phusis, that Tarkovsky seeks to overturn the modern representation of technology as subjectempowerment and open alternatives towards a non-instrumental conception. 
Were these principles taken seriously by film critics, the hermeneutic pursuit of allegorical symbolism or the poetic pursuit of narrative analysis would be precluded in favor of an opening to the medium of Tarkovsky's films as a mediation of life liberated from representation. Audio-visual technique, following the practice of haiku poetry, would bring forth a world uncontained by the rhetorical effects of literacy, an alogical world that " $[\ldots]$ retains all its agential capability without being mediated by us [...] a world that has been subjected to the workings of language and has come out unaffected " (Godzich, 1993, p. 20). Does this signify a general withdrawal of meaning or a loss of certitude? Perhaps. This may also explain why the modern, institutional study of film resists such a perspective. Yet it has its predecessors, for it bears the trace of an ontological rethinking of what Siegfried Kracauer has called "the affinities" the film medium has for unstaged reality, attracted as it is to the indeterminate, the fortuitous, the fragmentary and the endless aspects of everyday life (1960, p. 303). These affinities are images harboured-forth in haikutechnics, the metamorphic, temporal "film" of the life-world moving in light and in shadow.

\section{Auragraphy}

On a summer noon, resting, to follow the line of a mountain range on the horizon or a twig which throws its shadow on the observer, until the moment or hour begins to be a part of its appearance - that is to breathe the aura of those mountains, that twig (Benjamin, 1980 [1931], p. 209).

This snapshot cliché emerges out of Walter Benjamin's essay, "A Short History of Photography," like an image of the scene of haiku technics and may look like a belletristic gratuity. Yet it was written in order to elaborate a response to the question, "What is aura?" and the ambiguous metaphysical claim, "A strange web of time and space: the unique appearance of a distance however close at hand" (p. 206). It does not define a principle except insofar as it explores a haiku-like action carried 
on between an observer and a landscape in a summer season at the peak of the sun's cast of light. In the scene of this action, a specific duration and distance inscribe themselves, or breathe into, the material appearance of a shadow or a line: what may be called auragraphy ${ }^{7}$. Who is the observer? He is the haiku poet as photo-grapher, writing words of light.

Haiku poetry, like the camera, holds the power to arrest, to suspend, and to inscribe historical movement itself in the complex production of the image ${ }^{8}$. For Barthes, haiku poetry is a kind of photographic act because it performs the deixis of the interjection "so" and writes with "a flash or a slash of light" that illumines without revealing, "it is the flash of a photograph one takes very carefully (in the Japanese manner) but having neglected to load the camera with film" (p. 83). Yet for Benjamin the scene of haiku-technics haunts photography, and rather than captivate a technical impossibility of reproduction and a necessary absence of film in the apparatus, this scene is thought of at a particular historical juncture as an aural light glowing and fading through an apparitional medium and into which a material process(ion) of time and space casts a shadow'.

Apparitional medium may be understood as the duality of André Bazin's notion: to take a picture is to mold a death mask of the life-model as it is sculpted in the plasticity of light ${ }^{10}$. In this instance, the photographic medium does not merely liberate phenomena from their temporal succession. By "embalming" them, it marks a ghostly falling-away, a hazy glow, in the very emergence of their appearance ${ }^{11}$ The material process(ion) is not given immediately as a distance between two points in space; rather, the distance is perceived as a mediation of a rhythm, a material inscription of time accentuated periodically by a shadow or line.

The notion of photography as apparitional medium may be corroborated by Benjamin's remarks on the magical value of photographs since they irresistibly compel viewers to seek the coexistence of the future anterior in the flash of the here and now :

In such a picture, that spark has, as it were, burned through the person in the image with reality, finding 
the indiscernible place in the condition of that long past minute where the future is nesting, even today, so eloquently that we looking back can discover it (p. 202).

The notion of photography as material process(ion) is suggested by Benjamin's comments on a special relationship revealed by early time-lapse technique: "The procedure itself caused the models to live, not out of the instant, but into it; during the long exposure they grew, as it were, into the image" (p. 204).

Historically, Benjamin is interested in developing an image of the poor, unknown and melancholy photographer Eugène Atget, resting at noon and breathing in an aura at the scene of haiku technics. In the age of mechanical reproduction to which Atget belongs and that he paradoxically helps to usher within the reach of the mass movements of the twentieth century, this aura, shocked from its shell in a flash of light made more instantaneous with the technological development of the camera, marks itself as a detachment or falling-away. Although Benjamin never names the observer of this sun-shade landscape, nor describes Atget as a disconsolate wordsmith of lyric flashes and fragments, he does seek to capture, as in a negative-image, the double nature of the scene of haiku technics as practiced by " one of great ability who always lived in the shadows" documenting the appearance/disappearance of the aura in the silence, the absence, and the night of urban reality.

According to Benjamin, Atget made an exemplary itinerary in the history of photography and its printing - the beginnings of which, we learn in the opening of words of the essay, are enveloped in the obscurity of thick fog. For Atget never gave in to photographing urban-impressionist postcards nor was he swept up by the trend of making miniature portraits in studios with phony props; he resisted this and, with an obstinate devotion in connection with a clean precision, resided in the daily life that shown somewhere between faces and urban landscapes, beyond sham interiors and retouched exteriors. After all, "Atget was an actor who became disgusted with that pursuit, took off his mask and then went on to strip the makeup from reality as well" (p. 208). Benjamin writes that his images 
"[...] are not lonely but voiceless; the city in these pictures is swept clean like a house which has not yet found its new tenant" (p. 210).

For Benjamin, these effects foreshadow the politically educated sight of Surrealist photography, "which established a healthy alienation between environment and man". For Siegfried Kracauer, the melancholy invested in Atget's images is analogous to Proust's notion of photography as alienation :

[...] it favors self-estrangement, which on its part entails identification with all kinds of objects. The dejected individual is likely to lose himself in the incidental configurations of his environment, absorbing them with a disinterested intensity [...] (1960, p. 18).

Atget's photography rests between a melancholy receptivity to the light of urban thresholds and an healthy alienation from their shadows, between self-estrangement and worldestrangement, between errant wandering and homely dwelling, between voiceless silence and the breath of a distance. Haiku technics sets the scene, not for the representations of post-cards and portraits, but for this poetic practice of being in-between the proximity of the real, promised by mass reproductions, and the distance of the aura, marking its self-detachment from traditional contexts and gazes. In this sense, Atget's photographic practice crystallizes an important historical transition as it suspends and inscribes the breath of "the unique appearance of a distance however close at hand": auragraphy.

\section{Shadow Words}

Shadows and their words create the seasons; the intransitive shadows that touch the distance, the absence, and prenarrative silence (Vizenor, 1994, p. 65).

Gerald Vizenor, author of Manifest Manners: Postindian Warriors of Survivance (1994), writes about the cultural strategies of survivance for a people constructed by a racial and colonial discourse, designated in the categories of simulated 
representations, and observed and interpreted by the surveillance of ethnological practices. In this postindian predicament, itself in the shadow of the postmodern questioning of modernity, Vizenor observes and engages in a battle for a different kind of relationship to language and memory in order to intervene within this same discursive framework and its manifest manners of missionary zeal and dominance.

In the chapter entitled "Shadow Survivance," Vizenor discusses the central problematic of postindian literature. How does one inherit and generate a tribal presence originally mediated by an ancient form of orality, the dynamic, mobile and holophrastic nature of which has been contaminated, flattened, and misinterpreted by the literacy of an anthropological institution that has transformed its life-world into folk literature? Vizenor never loses a performative relationship to this question since literary theory and cultural practice are inseparable thrusts of the same dialogue, and the trickster hermeneutics he is fond of discussing form the groundwork of his own use of a theoretical language that cannot be easily situated. Nor should it be; to read his prose is not to localize nor to fix an authority of meaning but to engage in the work of the inheritance and the generation of a tribal presence, to dwell with shadows and their words, shadow words.

Postindian consciousness is a rush of shadows in the distance, and the trace of natural reason to a bench of stones; the human silence of shadows, and animate shadows over presence. The shadow is that sense of the intransitive motion to the referent; the silence in memories. Shadows are neither the absence of entities nor the burden of conceptual references. The shadows are the prenarrative silence that inherits the words; shadows are the motions that mean the silence, but not the presence or the absence of entities (1994, p. 64).

Shadow words project a way of surviving the narrative, causal and referential relationships to the literacy of print culture and the subject-centered epistemology of representation that it conditions. To transmit the shadows of this relationship is to undermine the determination of these conditions, and for 
example, to militate against the notion of a transparent and lucid reproducibility of presence or absence in language. Shadow words set off a line of flight, not in order to resuscitate a tribal paradise lost, but in order to mobilize a "re-membering" in prose, a putting-together of a people living in the ruins of the representations of the native, thinking through the half-light of this Indian identity, becoming postindian.
I hear the push of the wind in late summer, in the winter birch, and see the shadows hie over the shore in silence; and my shadows move with the light, the sources of remembrance. We are shadows, silence, stones, stories, never that simulation of light in the distance. Trickster stones and postindian stories are my shadows, the natural traces of liberation and survivance in the ruins of representation (p. 64).

This relationship to the shadows of language is also a relationship to the daily life of the world and the turn of the seasons. It is a relationship that allows Vizenor to speak of haiku as the "the intuition of shadow words: a concise mediation of sound, motion, memories, and the sensation of the seasons" (p. 65). Next, Vizenor cites R. S. Blythe, himself notable as a critic for linking Zen thinking to haiku poetics in Haiku: "Haiku is the result of the wish, the effort, not to speak, not to write poetry, not to obscure further the truth and suchness of a thing with words, with thoughts and feelings" (p. 65).

Between these two affirmations there is a problem that goes beyond the purview of the aesthetic search for the mot juste and which poses an epistemological questioning on the way the subject is set into language. The condition for the possibility of shadow words circulates in the subject's strange relationship to the scene of language, a scene that both reveals and conceals things in darkness and in light, between landscapes and a wordevents. For Blythe, this is the scene of an impossibility to which haiku poets are sensitive because they do not constitute themselves as subjects in order to integrate thoughts and feelings; instead they hold onto a threshold of attention at the limits of language, a threshold that does not reduce but marks the gesture where silence, distance and self coalesce. 
For Vizenor, this opens up the possibility of finding another relationship to language through haiku, as it is "a concise mediation" generating a field of action into which, through which, and out of which, the dynamic materiality of the world and the motions of memory run. This is consistent with Barthes' remarks of the privilege the haiku poem enjoys of escaping the rhetorical excesses of definition and description, not as a motif of "illumination" or "symbolic hyperesthesia" in which the subject is swollen with sense, nor as a gesture of "heavy, full, profound, mystical silence" through which the emptiness of the soul might be filled by the divine, but as an immense Zen praxis "to halt language" (1987 [1970], p. 74). Following Vizenor we might characterize the postindian subject as one who must inhabit language as on the ruins of a threshold, standing under the shadows of the intransitive motion to the referent, and moving into contact with the prenarrative silence that inherits words before they are invested with the power to name, to define, and to describe. The subject would not command language but become its medium of transit by tracing the seasons of daily life in a language that is paradoxically mobile and intransitive. A subject in touch with the motions and the incidents of the life-world "that mean the silence in memories", an intransitive silence that, while surviving virtually, cannot be reduced as the substrate of the representational knowledge of manifest manners.

Université de Montréal

\section{NOTES}

1 I borrow this terminology from Wlad Godzich, who characterises the determination of this change in historical terms much broader than, but nonetheless pertinent to turn of the century modernism. See: "The Language Market under the Hegemony of the Image", Eutopias Working Papers, vol. 29 (1993).

2 Reed Way Dasenbrock distinguishes this early poetics of the parataxis of concrete images from Pound's more generalized and epic poetics informing The Cantos in the 1930's through an "ideogrammic method" ("The Cantos in the Context of Vorticism," in The Literary Vorticism of Ezra Pound and Wyndham Lewis (Baltimore: Johns Hopkins University Press, 1985, p. 205).

3 This is my own paraphrastic thesis of the primary thrust of Martin Heidegger's related arguments in "The Question Concerning Technology" and "The Age of the

Theoretical Apparitions of Haiku: An Intermedial Interrogation of Modernity 
World Picture" from The Question Concerning Technology and Other Essays (New York: Harper \& Row Publishers, 1977).

4 I borrow Samuel Weber's equivocal title to Heidegger's famous essay in order to explore the questioning process, not as one that seeks a cognitive-informational definition, but as one that, moving like techné itself, opens a "free-relationship" to the matter at hand. See: Alan Cholodenko and Samuel Weber (ed.), "Upsetting the Set-Up” from Mass Mediauras: Form, Technics, Media (California: Stanford University Press, 1996).

5 As Gilles Deleuze demonstrates, this is not merely a formal principle but an intuition of a larger historical crisis elaborated between two opposing semiotic systems. Deleuze refers to Tarkovsky's theory in: "Récapitulation des images et des signes", L'Image-temps (Paris: Minuit, 1985, p. 60-61).

6 In light of these remarks, we may see how well Tarkovsky continued something of the post-symbolist modernism in the "Acmeist" impulses of Russian poetry (as embodied in the works of Anna Akhmatova and Osip Mandelstam, etc.), having inherited the explosion of poetic forms that took place even beyond the haiku form, extending for many generations and into the traceable influence of the film-maker's mentor-poet, his father, Arseney Tarkovsky. In this sense, Tarkovsky's cinematography, like the Acmeist "Guild of Poets", continued the search for a revolutionary economy of the image in the dynamic, concrete materiality of the world and in the search for the clarity and austere simplicity of the word. For a historical account of Acmeism see: Evelyn Bristol, A History of Russian Poetry (New York: Oxford University Press, 1991, p. 205-223).

7 Alain Buisine, in Eugène Atget ou la mélancolie en photographie (Nîmes: Éditions Jacqueline Chambon, 1994, p. 115-122), discusses the Latin etymology of aura as "air or breath, the physical laws of light-refraction producing the aural-effect", as well as the theoretical notion of aura informing the writings of Walter Benjamin.

8 Eduardo Cadava, in the preface to Words of Light: Theses on the Photography of History (New Jersey: Princeton University Press, 1997), recalls how Benjamin's writings, as "photographically thetic" writings, are faithful to the search for this kind of relationship: "Like the gaze of the camera that momentarily fixes history in an image, the thesis condenses a network of relations into a frame whose borders remain permeable" (p. XX).

9 Garrett Stewart opposes these terms helpfully in: "Modernism's Sonic Waiver" from Adalaide Kirby Morris (ed.), Sound States: Innovative Poetics and Acoustical Technologies (Chapel Hill: The University of North Carolina Press, 1997, p. 239).

10 André Bazin. "The Ontology of the Photographic Image", from What is Cinema?, vol. 1 (Berkeley: University of California Press, 1967, p 12-15).

11 Samuel Weber, in the chapter "Art, Aura and Medium in the Work of Walter Benjamin" (Alan Cholodenko and Samuel Weber (ed.), Mass Mediauras: Form, Technic, Media. California: Stanford University Press, 1996), connects this phenomenon intimitately with Heidegger's essay, "The Age of the World Picture" by discussing how the aura returns even in the age of televisual reproduction as the irreducible appearance of self-detachment: "The aura would then be something like an enabling limit, the emanation of an object from which it removes itself, a frame falling away from its picture and in its fall, in its Verfall, becoming light: a bright shadow" (p. 88). 


\section{WORKS CITED}

Barthes, Roland. The Empire of Signs. New York: Hill and Wang, 1982.

Bazin, André. What is Cinema?, vol. 1. Berkeley: University of California Press, 1967.

Benjamin, Walter. Classic Essays on Photography. New Haven: Leete's Island Books, 1980.

Bresson, Robert. Notes sur le cinématographe. Paris: Gallimard, 1975.

Derrida, Jacques. Of Grammatology. Baltimore: Johns Hopkins University Press, 1976.

Eisenstein, Sergueï. Film Form: Essays in Film Theory. Cleveland: The World Publishing Company, 1957.

Fenellosa, Ernest. The Chinese Written Character as a Medium for Poetry. San Francisco: City Lights Books, 1991.

Godzich, Wlad. "The Language Market under the Hegemony of the Image," Eutopias Working Papers, vol. 29 (1993).

Kracauer, Siegfried. Theory of Film: The Redemption of Physical Reality. New York: Oxford University Press Inc., 1960.

Lowe, Lisa. "The Desires of Postcolonial Orientalism: Chinese Utopias of Kristeva, Barthes, and Tel quel," from Critical Terrains: French and British Orientalisms. Ithaca: Cornell University I'ress, 1991.

Pound, Ezra. Literary Essays of Ezra Pound. New York: New Directions, 1970.

Pound, Ezra. Gaudier-Brzeska. A Memoir. New York: New Directions, 1970.

Pound, Ezra. Selected Poems of Ezra Pound. New York: New Directions, 1957.

Schneidau, Herbert. Ezra Pound: The Image and the Real. Baton Rouge: Louisiana State University Press, 1969.

Tarkovsky, Andrey. Sculpting in Time: Reflections on the Cinema. London: The Bodley Head, 1986.

Vizenor, Gerald. Manifest Manners: Postindian Warriors of Survivance. Hanover:

Wesleyan University Press, 1994.

Theoretical Apparitions of Haiku : An Intermedial Interrogation of Modernity 